\title{
A Specific Role for Saline or the Sodium Ion in the Regulation of Renin and Aldosterone Secretion
}

\author{
Michael L. Tuck, Robert G. Dluhy, and Gordon H. Williams \\ From the Endocrine-Metabolic Unit, Peter Bent Brigham Hospital, and the \\ Department of Medicine, Harvard Medical School, \\ Boston, Massachusetts 02115
}

A B S T R A C T It is well established that in normal man the renin-angiotensin-aldosterone system is responsive to changes in volume. The present study was performed to determine whether sodium has an action apart from volume in the regulation of the secretion of renin and aldosterone. Acute volume expansion was induced either by saline, dextran, or glucose infusion in supine, normal subjects in balance on a 10 meq sodium $/ 100$ meq potassium diet. Plasma renin activity (PRA), angiotensin II (A II), aldosterone (PA), cortisol, serum sodium, and potassium were measured every $10 \mathrm{~min}$ for the first $30 \mathrm{~min}$ and then at $1,2,4,6$, and $8 \mathrm{~h}$.

During saline infusion $\left(500 \mathrm{~cm}^{3} / \mathrm{h}\right.$ for $6 \mathrm{~h}$ ) mean PRA and A II levels declined very rapidly, falling significantly below control at $10 \mathrm{~min}(P<0.01)$ and by $50 \%$ at $60 \mathrm{~min}$. Thereafter, the rate of fall was more gradual, reaching a nadir at $360 \mathrm{~min}(70-80 \%$ below control). PA declined in a parallel pattern except that a significant fall did not occur until $30 \mathrm{~min}$.

In contrast to saline, dextran infusion $\left(250 \mathrm{~cm}^{3} / \mathrm{h}\right.$ for 4 h) did not produce a significant fall in PRA, A II, or PA until $4 \mathrm{~h}$ after the start of the infusion despite equivalent volume expansion. On the other hand, the infusion of $5 \%$ glucose and water $\left(500 \mathrm{~cm}^{3} / \mathrm{h}\right.$ for $\left.6 \mathrm{~h}\right)$ did not produce a significant decline in PRA, A II, or PA over the first $6 \mathrm{~h}$ of the study. Although the response rate of PRA, A II, and PA was different in each of the three infusion studies, these parameters were significantly correlated within each study. Serum sodium and potassium levels did not change during any study except dextran infusion, where a significant fall in both occurred at $120 \mathrm{~min}$. In all the infusion studies, plasma

Presented in part at the IV International Congress of Endocrinology, June 18-24, 1972, Washington, D. C.

Dr. Tuck's address is: Veterans Administration Hospital, 16111 Plummer Street, Sepulveda, California 91343.

Received for publication 3 August 1973 and in revised form 9 October 1973. cortisol levels gradually declined during the 8-h study period consistent with its expected rhythm of diurnal secretion.

These results demonstrate that rate of response of the renin-angiotensin-aldosterone system to acute volume expansion with saline differed from that with dextran and glucose infusion in sodium-depleted man. The data support a specific role for volume expansion with saline or the sodium ion per se in the regulation of renin and aldosterone.

\section{INTRODUCTION}

In normal man, volume expansion after sodium loading has been demonstrated to suppress the secretion of renin and aldosterone (1-5). A recent study, demonstrating a rapid suppression of blood levels of renin, angiotensin, and aldosterone after infusions of small volumes of saline, suggested a specific role for the sodium ion in the regulation of the renin-aldosterone axis (5).

To examine a role for the sodium ion per se, the renin, angiotensin, and aldosterone levels were measured after comparable volume expansion with saline and dextran. A possible difference in response between orally and intravenously administered sodium chloride was also investigated.

\section{METHODS}

Protocols. 19 normal subjects (13 men, 6 women) ranging in age from 21 to $33 \mathrm{yr}$, were studied in The Clinical Research Center of the Peter Bent Brigham Hospital. All subjects had a normal physical examination and routine laboratory tests, and denied use of medications. Written, informed consent was obtained in all cases. During hospitalization, they were maintained on a constant activity pattern simulating normal daily activity and were fed a constant 10 meq sodium $/ 100$ meq potassium, and a $2,500 \mathrm{~cm}^{3}$ isocaloric diet divided into three meals daily, and a small 
snack at bedtime (5-7). Studies were performed after the subject had achieved metabolic balance, usually on the 5 th or 6th day of dietary sodium restriction. 24-h urines were collected daily and analyzed for sodium, potassium, and creatinine. All studies were begun at 8 a.m. after an overnight fast and supine position for at least $12 \mathrm{~h}$. During infusion studies subjects remained fasting while blood samples were obtained every $10 \mathrm{~min}$ for $30 \mathrm{~min}$ and then at $1,2,4,6$, and $8 \mathrm{~h}$. Most subjects received a single study, but in four, both saline and dextran infusions were performed. Samples were assayed for renin activity by radioimmunoassay and bioassay of angiotensin II (A II), ${ }^{1}$ aldosterone, cortisol, sodium and potassium. In addition, the degree of volume expansion during saline and dextran infusion was assessed by changes in hematocrit levels at each time interval.

Intravenous saline infusion. Seven subjects (four men, three women) were given normal saline intravenously. 3 liters of $0.9 \%$ sodium chloride were infused at a constant rate of $500 \mathrm{ml} / \mathrm{h}$ for $6 \mathrm{~h}$ between 8 a.m. and 2 p.m.

Intravenous glucose infusion. Three male patients received intravenous glucose as a sham sodium infusion. 3 liters of $5 \%$ dextrose and water were infused at a constant rate of $500 \mathrm{ml} / \mathrm{h}$ for $6 \mathrm{~h}$ from 8 a.m. to 2 p.m. in a manner identical to that used for the intravenous saline study. Plasma determinations were the same except A II levels were not measured.

Intravenous dextran infusion. Five subjects (four men, one woman) received an intravenous infusion of low molecular weight dextran (average mol wt, 40,000). Dextran 40 in $5 \%$ dextrose and water (Rheomacrodex, Pharmacia Laboratories Inc., Piscataway, N. J.) was infused at a constant rate of $250 \mathrm{ml} / \mathrm{h}$ for $4 \mathrm{~h}$ ( 8 a.m. -12 noon). The volume of dextran infused was calculated to give an intravascular volume expansion comparable to the normal saline. This calculation was based on their relative volumes of distribution (8). Since dextran also causes water to migrate into the intravascular space, the amount of intravascular volume expansion was probably greater with dextran, a fact supported by the greater fall in hematocrit with dextran than with saline infusion. Only a 4-h infusion of dextran $\left(1,000 \mathrm{~cm}^{3}\right)$ was given, in compliance with the recommendation of the manufacturer. In addition, subjects with a history of allergy were not used, and all were constantly monitored by a physician, who was in attendance during the infusions. To assess the possibility of variation in patient response, four subjects received both a saline and dextran infusion. At least 5-6 days were used between studies to reestablish metabolic balance.

Oral sodium loading. Five subjects (two men and 3 women) ingested sodium chloride in an amount equivalent to that administered in the intravenous saline study. 3 liters of bouillon (150 meq sodium, $2 \mathrm{meq}$ potassium/liter) were ingested at a rate of $500 \mathrm{ml} / \mathrm{h}$ for $6 \mathrm{~h}$ ( 8 a.m. -2 p.m.). All subjects were encouraged to ingest the bouillon at a steady rate and all tolerated the procedure without side effects.

Laboratory procedures. All blood samples were immediately spun and the plasma was separated and frozen until time for assay. The samples for plasma renin activity (PRA) and A II levels were drawn with EDTA as the anticoagulant; cortisol and aldosterone samples were collected with heparin as the anticoagulant. Diisofluorophos-

\footnotetext{
${ }^{1}$ Abbreviations used in this paper: A II, angiotensin II; PA, plasma aldosterone; PRA, plasma renin activity.
}

phate was also added to the samples for A II assay. Sodium and potassium in urine and blood were measured by flame photometry with lithium as an internal standard.

Plasma aldosterone (PA) and cortisol were measured by displacement analysis techniques as previously described (9). A II values were measured by a double antibody radioimmunoassay method (10). This assay was sensitive to a level of $7 \mathrm{pg} / \mathrm{ml}$ with a coefficient of variation at the $20 \mathrm{pg} / \mathrm{ml}$ level of $6.8 \%$. Recoveries of added A II at three different levels ranged from 88 to $108 \%$. PRA was measured both by a modification of the Boucher method as previously described (11) and by a radioimmunoassay procedure (10).

Statistical evaluation. Responses were analyzed statistically by computing a $t$ value for the response at each time interval compared with its appropriate control with the pooled variance as derived from a two-way analysis of variance.

The computations were done on the log transforms of the data. In all cases the variance was assessed as being homogenous on the log transformed data by Bartlett's test (12). $P$ values were found in Dunnett's tables for comparing multiple tests with a single control (13). Missing data points were estimated by the appropriate method for randomized blocks (14) before the two-way analysis of variance on the $\log$ transform. The results are expressed as mean \pm standard error of the mean and significance was $P<0.01$ unless otherwise indicated. Nonsignificant differences were those with $P>0.05$. A copy of the individual responses will be supplied by the authors on request.

\section{RESULTS}

The absolute plasma levels of renin activity, A II, aldosterone, and cortisol in the present study were similar to those previously recorded by our laboratory and in reasonable agreement with other investigators when one considers variations in dietary intake of sodium and potassium (15-17), and differences in posture (4-7).

Intravenous saline infusion. The mean 24-h urine sodium and potassium excretion on the day before, during, and after the study were $11 \pm 2$ and $70 \pm 6$ meq; $181 \pm$ 16 and $72 \pm 3$ meq; and $125 \pm 8$ and $77 \pm 4$ meq, respectively. Of the 450 meq sodium infused, 306 meq ( $63 \%)$ was excreted on the day of and the day after the saline infusion. The mean weight gain due to the saline infusion $(1.7 \pm 0.2 \mathrm{~kg})$ was not significantly different from the mean weight loss during sodium restriction $(1.8 \pm 0.2$ $\mathrm{kg}$ ). The mean serum sodium did not vary during the course of the study, while only at the last time interval (480 min) did the mean potassium level significantly decline below control levels. During saline infusion, there was a fall in hematocrit levels from $43 \%$ to $41 \%$ at $60 ; 40 \%$ at 120 ; and $39 \%$ at $240 \mathrm{~min}$, representing a mean fall from base line after $4 \mathrm{~h}$ of infusion of $9 \%$.

The mean control values of PRA (bioassay and radioimmunoassay), A II, and aldosterone are presented in Table I. The mean PRA had a similar response pattern whether measured by radioimmunoassay or bioassay. In general, the radioimmunoassay and bioassay 
TABLE I

Response of PRA, A II, Aldosterone, Cortisol, Serum Sodium, and Potassium to Saline Infusion in Supine, Normal Subjects on a 10 meq Sodium/100 meq Potassium Intake

\begin{tabular}{|c|c|c|c|c|c|c|c|}
\hline \multirow[b]{2}{*}{ Time } & \multirow{2}{*}{$\begin{array}{c}\text { PRA } \\
\text { (bioassay) }\end{array}$} & \multirow{2}{*}{$\begin{array}{c}\text { PRA } \\
\text { (radioimmunoassay) }\end{array}$} & \multirow[b]{2}{*}{ A II } & \multirow[b]{2}{*}{ PA } & \multirow{2}{*}{$\begin{array}{l}\text { Plasma } \\
\text { cortisol }\end{array}$} & \multicolumn{2}{|c|}{ Electrolytes } \\
\hline & & & & & & Sodium & Potassium \\
\hline $\min$ & $\mathrm{ng} / 100 \mathrm{ml} / 3 \mathrm{~h}$ & $\mathrm{ng} / 100 \mathrm{ml} / 3 \mathrm{~h}$ & $p g / m l$ & $\mathrm{ng} / 100 \mathrm{ml}$ & $\mu \mathrm{g} / 100 \mathrm{ml}$ & \multicolumn{2}{|c|}{ meq/liter } \\
\hline 0 & $1,390 \pm 315$ & $1,950 \pm 500$ & $69 \pm 13$ & $36 \pm 3$ & $12 \pm 1$ & $141 \pm 1$ & $4.3 \pm 0.1$ \\
\hline 10 & $1,120 \pm 275$ & $1,470 \pm 300$ & $51 \pm 9$ & $33 \pm 3$ & $11 \pm 1$ & $141 \pm 1$ & $4.3 \pm 0.1$ \\
\hline 20 & $855 \pm 275$ & $1,420 \pm 250$ & $47 \pm 6$ & $28 \pm 3$ & $10 \pm 1$ & $142 \pm 1$ & $4.4 \pm 0.1$ \\
\hline 30 & $860 \pm 375$ & $1,310 \pm 230$ & $42 \pm 5$ & $21 \pm 3$ & $9 \pm 1$ & $140 \pm 2$ & $4.4 \pm 0.1$ \\
\hline 60 & $590 \pm 170$ & $970 \pm 250$ & $36 \pm 6$ & $17 \pm 2$ & $8 \pm 1$ & $140 \pm 1$ & $4.2 \pm 0.1$ \\
\hline 120 & $590 \pm 190$ & $815 \pm 210$ & $33 \pm 5$ & $15 \pm 2$ & $8 \pm 1$ & $140 \pm 1$ & $4.3 \pm 0.1$ \\
\hline 240 & $560 \pm 160$ & $550 \pm 150$ & $28 \pm 4$ & $14 \pm 2$ & $6 \pm 1$ & $140 \pm 2$ & $4.2 \pm 0.1$ \\
\hline 360 & $350 \pm 100$ & $330 \pm 135$ & $23 \pm 4$ & $11 \pm 2$ & $4 \pm 1$ & $139 \pm 1$ & $4.1 \pm 0.1$ \\
\hline 480 & $360 \pm 100$ & $290 \pm 60$ & $21 \pm 3$ & $9 \pm 1$ & $4 \pm 1$ & $140 \pm 1$ & $4.1 \pm 0.1$ \\
\hline
\end{tabular}

Results are means $\pm S E M$. Saline was infused at a rate of $500 \mathrm{~cm}^{3} / \mathrm{h}$ for $6 \mathrm{~h}$.

determinations were similar when the PRA was in the normal range, while the radioimmunoassay estimated a larger value when the PRA values were high and a smaller value when the PRA values were low, when

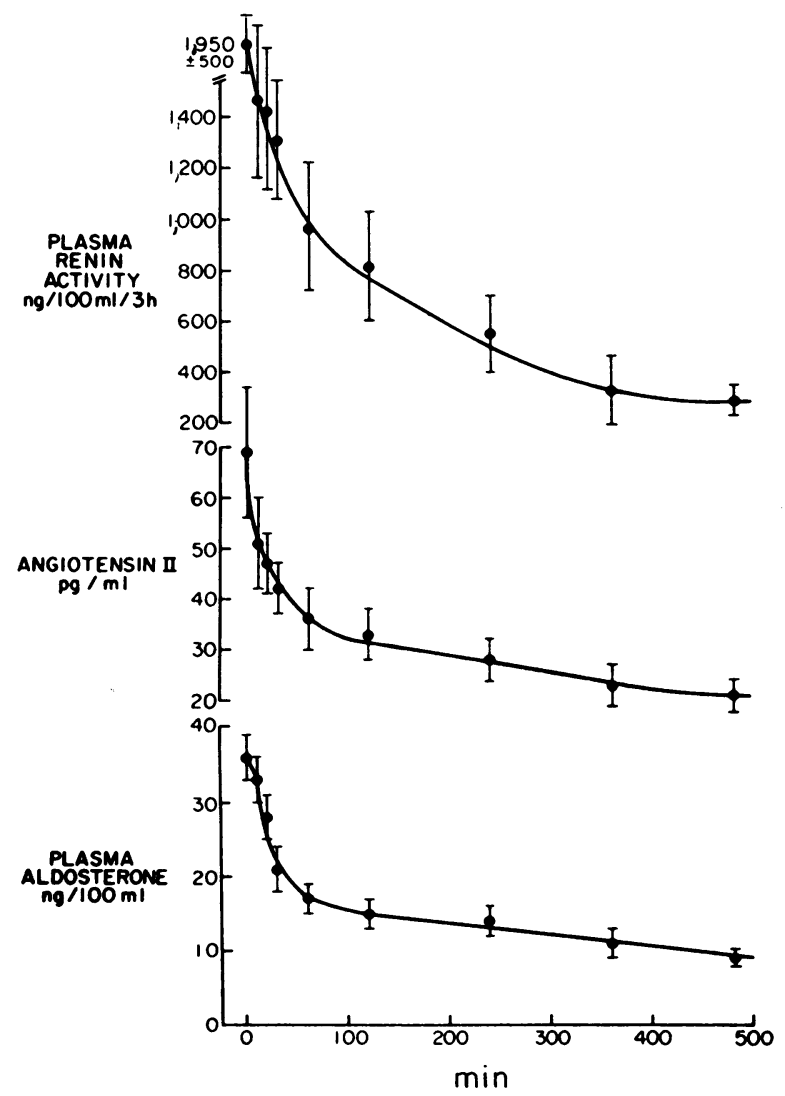

FIGURE 1 Mean response of PRA, A II, and aldosterone to the infusion of normal saline at a rate of $500 \mathrm{~cm}^{3} / \mathrm{h}$ for $6 \mathrm{~h}$. compared with values obtained by bioassay. The mean PRA levels declined rapidly after the start of the saline infusion with a significant fall by $10 \mathrm{~min}$ and a $50 \%$ decline by $60 \mathrm{~min}$ (Fig. 1). Thereafter, the decline was more gradual, reaching a nadir at $360 \mathrm{~min}$ at a level $80 \%$ below control. Plasma A II responded in a similar fashion. The pattern of response of PRA and A II to saline infusion was significantly correlated $(r=0.75$, $P<0.001)$. PA levels also declined significantly during the course of the infusion and were significantly correlated with both A II and PRA levels $(r=0.79,0.84$, $P<0.001)$. However, there was an initial delay in the fall of PA with no significant change during the first $20 \mathrm{~min}$ of the infusion and then a rapid decline to $50 \%$ below control by $60 \mathrm{~min}$ (Fig. 1). During the saline infusion, the mean plasma cortisol levels showed only the expected diurnal changes.

Intravenous glucose infusion. In contrast to the saline infusion, the three subjects receiving a sham saline infusion of $5 \%$ glucose and water showed no significant alterations in their PRA values over the first $240 \mathrm{~min}$ of the infusion. A gradual decline followed, so that by 480 min, the PRA had decreased by $35 \%$ below base line, a pattern consistent with the previously described diurnal rhythm in supine, normal subjects $(7,15,18$, 19). Likewise, the mean control PA level showed no decline during the first $4 \mathrm{~h}$ of the infusion and then a gradual decline to $47 \%$ below base line by $480 \mathrm{~min}$.

Intravenous dextran infusion. The mean 24-h excretion for sodium and potassium were $7 \pm 1$ and $73 \pm 3$ meq, respectively, on the day before the study; $6 \pm 1$ and $65 \pm 3$ meq on the study day; and $7 \pm 2$ and $68 \pm 4$ meq on the post-infusion day. Mean weight gain from the morning before dextran infusion to the morning after dextran infusion was $1.2 \pm 0.1 \mathrm{~kg}$, whereas the mean weight loss during dietary sodium restriction was $1.6 \pm 0.2 \mathrm{~kg}$. In 
TABLE II

Response of PRA, A II, Aldosterone, Cortisol, Serum Sodium, and Potassium to Dextran Infusion in Supine, Normal Subjects on a 10 meq Sodium/100 meq Potassium Intake

\begin{tabular}{|c|c|c|c|c|c|c|c|}
\hline \multirow[b]{2}{*}{ Time } & \multirow{2}{*}{$\begin{array}{c}\text { PRA } \\
\text { (bioassay) }\end{array}$} & \multirow{2}{*}{$\begin{array}{c}\text { PRA } \\
\text { (radioimmunoassay) }\end{array}$} & \multirow[b]{2}{*}{ A II } & \multirow[b]{2}{*}{ PA } & \multirow{2}{*}{$\begin{array}{l}\text { Plasma } \\
\text { cortisol }\end{array}$} & \multicolumn{2}{|c|}{ Electroly tes } \\
\hline & & & & & & Sodi'm & Potassium \\
\hline $\min$ & $n g / 100 \mathrm{ml} / 3 \mathrm{~h}$ & $\mathrm{ng} / 100 \mathrm{ml} / 3 \mathrm{~h}$ & $p g / m l$ & $n g / 100 \mathrm{ml}$ & $\mu g / 100 \mathrm{ml}$ & \multicolumn{2}{|c|}{ meilliter } \\
\hline 0 & $940 \pm 130$ & $1,340 \pm 230$ & $41 \pm 6$ & $31 \pm 4$ & $14 \pm 1$ & $145 \pm 3$ & $4.2 \pm 0.1$ \\
\hline 10 & $875 \pm 50$ & $1,290 \pm 290$ & $40 \pm 7$ & $30 \pm 4$ & $13 \pm 1$ & $146 \pm 3$ & $4.3 \pm 0.1$ \\
\hline 20 & $960 \pm 80$ & $1,130 \pm 390$ & $41 \pm 7$ & $29 \pm 5$ & $13 \pm 1$ & $143 \pm 3$ & $4.2 \pm 0.1$ \\
\hline 30 & $930 \pm 80$ & $1,230 \pm 200$ & $40 \pm 5$ & $32 \pm 5$ & $12 \pm 1$ & $139 \pm 2$ & $4.0 \pm 0.1$ \\
\hline 60 & $780 \pm 110$ & $1,240 \pm 260$ & $37 \pm 7$ & $33 \pm 6$ & $11 \pm 1$ & $137 \pm 2$ & $4.1 \pm 0.2$ \\
\hline 120 & $720 \pm 110$ & $1,220 \pm 190$ & $34 \pm 8$ & $26 \pm 6$ & $10 \pm 1$ & $139 \pm 4$ & $4.1 \pm 0.2$ \\
\hline 240 & $630 \pm 110$ & $1,020 \pm 80$ & $28 \pm 4$ & $16 \pm 2$ & $9 \pm 1$ & $136 \pm 4$ & $3.9 \pm 0.1$ \\
\hline 360 & $630 \pm 110$ & $900 \pm 80$ & $23 \pm 6$ & $11 \pm 3$ & $8 \pm 1$ & $139 \pm 3$ & $3.9 \pm 0.2$ \\
\hline 480 & $315 \pm 24$ & $620 \pm 50$ & $19 \pm 4$ & $8 \pm 2$ & $6 \pm 1$ & $138 \pm 3$ & $3.9 \pm 0.2$ \\
\hline
\end{tabular}

Results are means \pm SEM. Dextran was infused at a rate of $250 \mathrm{~cm}^{3} / \mathrm{h}$ for $4 \mathrm{~h}$.

contrast to the saline infusion study, both serum sodium and potassium levels declined during the dextran infusion. While there was no significant change over the first $2 \mathrm{~h}$ of the study, serum potassium levels were significantly lower than control at 240,360 , and $480 \mathrm{~min}$. Serum sodium levels declined from $145 \mathrm{meq}$ to $139 \mathrm{meq} /$ liter at $120 \mathrm{~min}$ and then remained stable throughout the

TABLE III

Response of PRA and Aldosterone to Saline and Dextran Infusion in the Same Individual. (The Study Sequence Was in the Order Listed)

\begin{tabular}{|c|c|c|c|c|c|c|}
\hline \multirow[b]{2}{*}{ Patient } & \multirow[b]{2}{*}{ Study } & & \multicolumn{4}{|c|}{ Time after start of infusion } \\
\hline & & & $\underset{\min }{\mathbf{0}}$ & $\begin{array}{c}30 \\
\min \end{array}$ & $\begin{array}{c}60 \\
\min \end{array}$ & $\begin{array}{l}120 \\
\min \end{array}$ \\
\hline \multirow[t]{4}{*}{1} & Saline & *PRA & 670 & 450 & 400 & 290 \\
\hline & & $\ddagger \mathrm{PA}$ & 20 & 14 & 11 & 10 \\
\hline & Dextran & PRA & 600 & 580 & 630 & 460 \\
\hline & & PA & 23 & 20 & 20 & 21 \\
\hline \multirow[t]{4}{*}{2} & Dextran & PRA & 840 & 890 & 640 & 510 \\
\hline & & PA & 37 & 45 & 43 & 43 \\
\hline & Saline & PRA & 1,090 & 800 & 620 & 540 \\
\hline & & PA & 46 & 26 & 20 & 20 \\
\hline \multirow[t]{4}{*}{3} & Dextran & PRA & 1,320 & 1,250 & 1,270 & 1,125 \\
\hline & & PA & 57 & 53 & - & 57 \\
\hline & Saline & PRA & 1,620 & 1,330 & 720 & 740 \\
\hline & & PA & 59 & 46 & 32 & 21 \\
\hline \multirow[t]{4}{*}{4} & Dextran & PRA & 1,440 & 1,460 & 1,380 & 1,320 \\
\hline & & PA & 30 & 27 & 25 & 20 \\
\hline & Saline & PRA & 1,150 & 810 & 600 & 510 \\
\hline & & PA & 32 & 24 & 16 & - \\
\hline
\end{tabular}

* PRA, in $\mathrm{ng} / 100 \mathrm{ml} / 3 \mathrm{~h}$.

$\ddagger$ PA in $\mathrm{ng} / 100 \mathrm{ml}$. rest of the infusion. Likewise, dextran infusion produced a fall in hematocrit from $43 \%$ base line value to $40 \%$ at $60 \mathrm{~min}$, and a significant fall to $38 \%$ at 120 and $36 \%$ at $240 \mathrm{~min}$. This represented a fall in hematocrit below base line to the 240 -min period, significantly greater than that produced during saline infusion.

The mean and range of the control levels before dextran infusion were not significantly different from those observed before saline or dextrose and water infusions (Table II). In contrast to saline, infusion of dextran was not accompanied by a significant decline in mean PRA levels until 240-360 min after the start of the infusion (Fig. 2). While the decline of PRA was less rapid than with saline, it was still significantly more rapid than with dextrose and water. The A II levels showed a similar delayed response pattern, with a significant fall below base line occurring at $240 \mathrm{~min}$. A II and PRA were again correlated $(r=0.55, P<$ 0.025). The mean PA level also showed no significant change until $240 \mathrm{~min}$. Changes in PA were significantly correlated with changes both in PRA $(r=0.62, P<$ $0.001)$ and A II $(r=0.56, P<0.001)$. However, the mean aldosterone levels declined more rapidly than PRA and A II in the last three sampling periods. This may reflect the effect of the lower serum potassium levels at these times, although there was no significant overall correlation between changes in these two parameters.

Paired infusion studies. In four subjects, both dextran and saline infusions were performed to assess if subject variation could account for the differences in the responses to dextran and saline. In one, saline was infused first, in the others, dextran. At least 5-6 days elapsed between each study. The individual PRA and aldosterone responses in these studies, as shown in Table III, are similar to the mean responses in Tables I and II. 
Saline ingestion. The mean 24 -h sodium and potassium excretion on the day before the study was $13 \pm 2$ and $72 \pm 4$ meq; on the study day, $132 \pm 10$ and $77 \pm 4$ meq; on the day after saline ingestion, $156 \pm 8$ and $81 \pm 5$ meq. The mean weight gain was $1.4 \pm 0.1 \mathrm{~kg}$, whereas the mean weight loss induced by the sodium-restricted diet was $1.6 \pm 0.2 \mathrm{~kg}$. The total sodium excreted on the day of and the day after the study was 288 meq, lower but not significantly less than that excreted during the intravenous saline infusion study. There were no significant changes in serum sodium or potassium during the study, and mean plasma cortisol levels showed a normal diurnal decline.

In comparison to intravenous saline administration, there was a lag in the rate of decline of PRA so that a significant decline did not occur until 30-60 min after the start of the saline ingestion (Table IV). This was still significantly more rapid than with dextran or dextrose infusion. Over the next $4 \mathrm{~h}$, however, the rate of decline was similar to that seen with saline infusion. The changes in plasma aldosterone levels were significantly correlated with changes in PRA $(r=0.56, P<$ 0.001 ), although a significant fall occurred somewhat later $(60-120 \mathrm{~min})$.

Plasma cortisol responses. The pattern of change in plasma cortisol was similar in the four studies. Plasma cortisol showed a $20-30 \%$ fall from base line between 60-120 min and a 50-75\% decline by the end of the study, a pattern in agreement with previously reported diurnal changes from our laboratory (7). Since the changes in plasma cortisol were similar in all four studies, it is unlikely that ACTH mediated the recorded differences in rate of response of PA. In fact, during saline infusion, PA had fallen more than $50 \%$ below control at $60 \mathrm{~min}$, whereas plasma cortisol had fallen only by $30 \%$. On the other hand, during dextran infusion, there was no significant change in PA at 60 min despite a $20 \%$ fall of plasma cortisol levels.

\section{DISCUSSION}

There have been few investigations of the acute responsiveness of the renin-angiotensin-aldosterone axis. Assumption of the upright posture or acute volume depletion after furosemide administration have both been reported to produce significant increments in PA levels within $30-60 \mathrm{~min}(20-22)$. Return to the supine position led to a $50 \%$ fall in PRA within 5-10 min (21). Studies of acute volume expansion have been limited but suggest a rapid suppression of renin and aldosterone secretion. Pickens and Enoch reported that PRA fell $37 \%$ from control $4 \mathrm{~h}$ after volume expansion with 500 $\mathrm{ml}$ dextran infusion (23). Kem, Weinberger, Mayes, and Nugent described that plasma aldosterone levels fall to less than $50 \%$ of control after a 4 -h saline infusion (2
PLASMA RENIN ACTIVITY

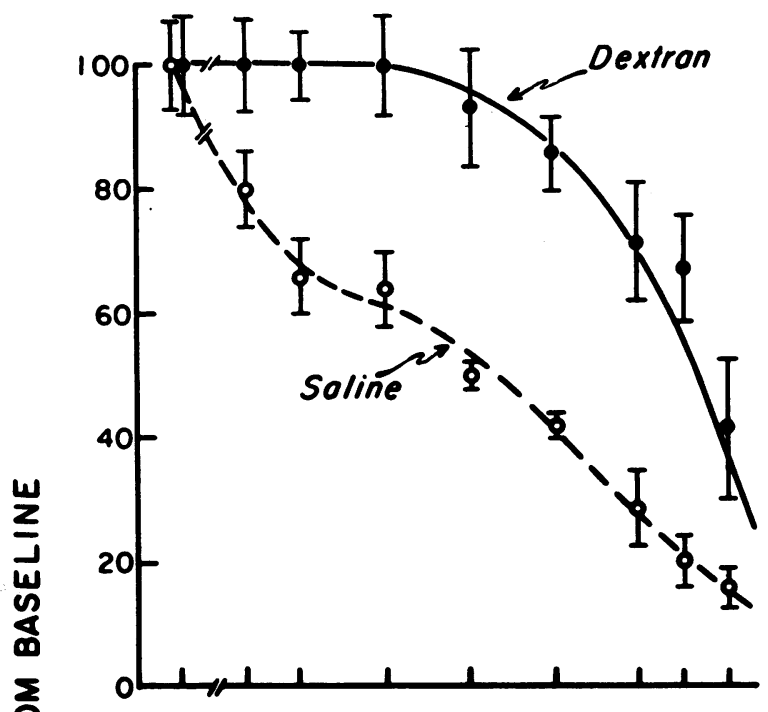

PLASMA ALDOSTERONE

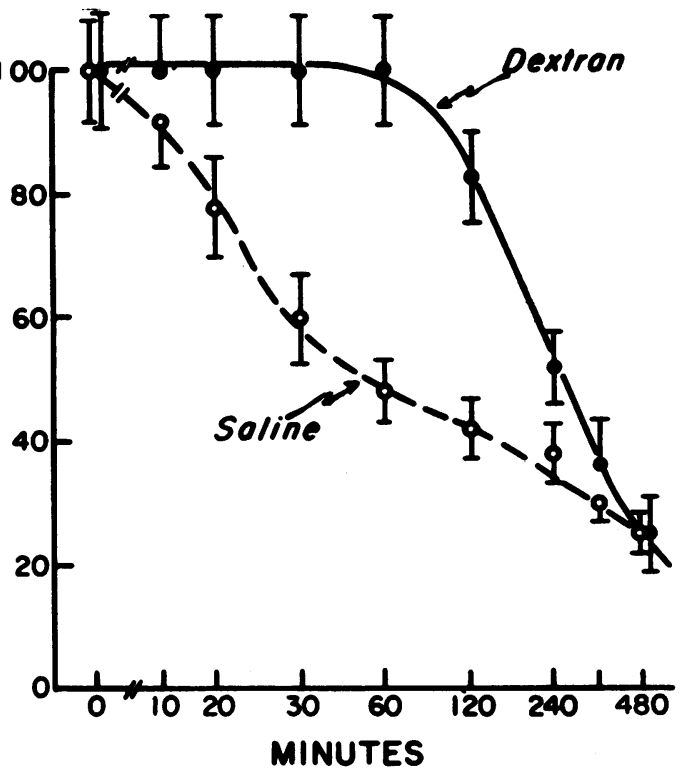

Figure 2 Comparison of the rate of response of PRA and aldosterone to saline and dextran infusions. Results are expressed as the mean $\pm \mathrm{SEM} \%$ fall from the base line plotted against time on a $\log$ scale.

liters) and assumption of the supine position (4). The present study extends these observations during the early time period $(0-60 \mathrm{~min})$ and demonstrates that in the sodium-depleted state, the renin-angiotensin-aldosterone axis can be rapidly suppressed by small volumes of sodium chloride. With intravenously administered normal saline, a significant $(P<0.01)$ fall in the level of renin activity and A II occurred at $10 \mathrm{~min}$ and 
TABLE IV

Response of PRA, Aldosterone, Cortisol, Serum Sodium, and Potassium to Saline Ingestion in Supine, Normal Subjects on a 10 meq Sodium/100 meq Potassium Intake

\begin{tabular}{|c|c|c|c|c|c|c|}
\hline \multirow[b]{2}{*}{ Time } & \multirow[b]{2}{*}{$\begin{array}{c}\text { PRA } \\
\text { (bioassay) }\end{array}$} & \multirow[b]{2}{*}{$\begin{array}{l}\text { PRA } \\
\text { (radioimmunoassay) }\end{array}$} & \multirow[b]{2}{*}{ PA } & \multirow[b]{2}{*}{$\begin{array}{l}\text { Plasma } \\
\text { cortisol }\end{array}$} & \multicolumn{2}{|c|}{ Electrolytes } \\
\hline & & & & & Sodium & Potassium \\
\hline $\min$ & $n g / 100 \mathrm{ml} / 3 \mathrm{~h}$ & $\mathrm{ng} / 100 \mathrm{ml} / 3 \mathrm{~h}$ & $\mathrm{ng} / 100 \mathrm{ml}$ & $\mu \mathrm{g} / 100 \mathrm{ml}$ & \multicolumn{2}{|c|}{ meq/liter } \\
\hline 0 & $940 \pm 160$ & $1,320 \pm 130$ & $29 \pm 7$ & $13 \pm 1$ & $143 \pm 1$ & $4.2 \pm 0.1$ \\
\hline 10 & $840 \pm 120$ & $1,350 \pm 175$ & $23 \pm 5$ & $11 \pm 1$ & $143 \pm 1$ & $4.1 \pm 0.1$ \\
\hline 20 & $760 \pm 140$ & $1,250 \pm 230$ & $21 \pm 3$ & $11 \pm 1$ & $143 \pm 1$ & $4.0 \pm 0.1$ \\
\hline 30 & $670 \pm 110$ & $1,130 \pm 310$ & $21 \pm 3$ & $10 \pm 1$ & $142 \pm 1$ & $4.0 \pm 0.3$ \\
\hline 60 & $610 \pm 100$ & $960 \pm 270$ & $16 \pm 2$ & $9 \pm 1$ & $142 \pm 3$ & $4.1 \pm 0.3$ \\
\hline 120 & $545 \pm 75$ & $740 \pm 160$ & $12 \pm 2$ & $7 \pm 1$ & $143 \pm 2$ & $4.2 \pm 0.2$ \\
\hline 240 & $400 \pm 70$ & $300 \pm 75$ & $10 \pm 1$ & $7 \pm 1$ & $142 \pm 1$ & $4.2 \pm 0.1$ \\
\hline 360 & $320 \pm 90$ & $130 \pm 36$ & $8 \pm 2$ & $6 \pm 1$ & $142 \pm 1$ & $4.1 \pm 0.3$ \\
\hline 480 & $230 \pm 50$ & $100 \pm 25$ & $5 \pm 1$ & $5 \pm 1$ & $144 \pm 2$ & $4.2 \pm 0.1$ \\
\hline
\end{tabular}

Results are means \pm SEM. Bouillon, 150 meq NaCl/liter, was ingested at a rate of $500 \mathrm{~cm}^{3} / \mathrm{h}$ for $6 \mathrm{~h}$.

of aldosterone at $30 \mathrm{~min}$. In contrast to saline, dextran infusion did not produce a significant fall in circulating levels of angiotensin and aldosterone until 240 min, while glucose infusion required more than 360 $\min$.

From the data available, both from the present and previous studies, it is difficult to precisely determine the sensitivity of the renin-angiotensin system to saline infusion in sodium-depleted man. However, the minimum sensitivity can be estimated from the renin half-life, if one assumes complete suppression of renin secretion after saline infusion. In all probability, a gradual suppression occurs, and therefore, the sensitivity would be greater than that calculated from the half-life determination. There is considerable discrepancy in the literature regarding the biologic half-life of renin. From the studies of Oparil, Vassaux, Sanders, and Haber in normal man, as estimated by a $50 \%$ fall from the upright to the supine position, the half-life of renin activity appears to be between 5 and $6 \mathrm{~min}$ (21). Michelakis and Mizukoshi reported that the disappearance rate of renin in man after nephrectomy was approximately 14 $\min (24)$. Furthermore, there is recent evidence that the hepatic clearance of renin is influenced by sodium intake, with sodium depletion decreasing hepatic clearance of renin (25). Because of these difficulties, it is not possible to determine in the present study the biologic half-life of renin precisely. If one assumes a renin half-life between 5 and $15 \mathrm{~min}$, and no significant change in its metabolic clearance rate during the first 30-60 min of the infusion, then the amount of saline required to produce a $50 \%$ fall in renin activity $(30-60 \mathrm{~min})$ would be an estimate of the minimum sensitivity. Thus, it can be concluded that the system was sensitive to as little as 20-60 meq of sodium chloride, and/or $125-400$ $\mathrm{ml}$ of volume. With saline ingestion, with a $10 \%$ rate of absorption of sodium from the small bowel and no absorption from the stomach (26), and a $t$ gastric emptying rate of 5-7 $\min (27)$, a 45-60 min lag time would be anticipated before a similar amount of sodium chloride was absorbed. This was approximately the time difference in the renin response rate between oral and intravenous saline administration.

The mechanism producing the rapid suppression of renin and aldosterone secretion by acute sodium repletion is not entirely apparent from the present studies. It has been previously shown that there is a diurnal fall in plasma levels of aldosterone, A II, and renin activity in normal, sodium-depleted man $(7,15,18,19)$. Because these studies were extended over a $6-8 \mathrm{~h}$ period, diurnal variation could account in part for a decline in aldosterone levels. However, the differences in rates of response of the renin-angiotensin-aldosterone axis are unlikely to be ACTH-mediated since the changes in plasma cortisol were similar in all infusion studies. A second possibility would be a local vascular reflex due to the intravenous infusion of fluids with a rapid alteration in adrenergic tone to the kidney, thereby altering renin secretion. However, it would be anticipated that under these circumstances all infusion studies would produce a similar response pattern. In addition, orally administered saline produced a response pattern similar to that of intravenous saline, when one takes into consideration the delay in absorption from the gastrointestinal tract.

It is also unlikely that the experimental design can account for the differences in the response rates to saline and dextran infusion. The fact that intravascular volume expansion, as reflected in hematocrit changes, was nearly identical makes differences in the degree of volume expansion an unlikely explanation for these observations. The overlap of the mean values and ranges 
for control parameters for the two studies would suggest that the subjects were in the same balance state before the start of the infusion. Not only were the mean response rates significantly different in the two infusion studies, but there was no overlap of the individual responses. The range of time to achieve a significant fall in renin activity, for example, was 10-35 min with saline infusion but $140-480 \mathrm{~min}$ with dextran. It is also improbable that subject selection can explain the difference in response since in the four subjects who received both studies, the same differences in response rate to saline and dextran were observed.

Since dextran and saline produced comparable changes in intravascular volume, the difference in the response of the renin-angiotensin-aldosterone axis might reflect their different effects on interstitial fluid volume. Saline expands intravascular and interstitial compartments; dextran also expands intravascular volume but decreases interstitial and possibly intracellular fluid volumes. Thus, the present data could be interpreted as showing stimulation of the renin-angiotensin system by dextran through contraction of some component of extravascular volume as opposed to suppression by saline and/or the sodium ion. However, expansion of intravascular volume and the contraction of interstitial volume was eventually associated with suppression of these parameters, as evidenced by the difference in rate of response of PRA to dextran in contrast to glucose infusion. Moreover, levels of renin, angiotensin, and aldosterone never increased after infusion of dextran, but only exhibited a delayed suppression. Another possibility is that the renin-angiotensin-aldosterone system can be suppressed by expansion of either interstitial or intravascular compartments. However, to explain the absence of rapid suppression after dextran infusion, this hypothesis would require the unlikely circumstance that the stimulation induced by contraction of interstitial fluid volume was of equal and opposite magnitude as the suppression produced by intravascular expansion. This hypothesis also fails to explain the suppression produced by dextran infusion after a 120-min lag. Thus, the present data best support the hypothesis that the either sodium ion per se or extracellular volume expansion with saline mediates this rapid response. Although our study does not clarify the sensing mechanism, possibilities include the macula densa of the kidney, which is detecting small changes in the sodium load (28), or an extrarenal baroreceptor, (29) or a central nervous system receptor (30) with transmittal of its input to the kidney via the adrenergic system.

\section{ACKNOWLEDGMENTS}

The technical assistance of E. Frochaux, R. Emanuel, N. Lymburner, and J. Young is gratefully acknowledged.

These investigations were supported in part by the Smith Kline \& French Foundation and the John A. Hartford
Foundation, Grant 9893. The clinical studies were carried out on The Clinical Research Center of the Peter Bent Brigham Hospital supported by Grant 8-M01-FR-31-06.

\section{REFERENCES}

1. Duncan, L. I., Jr., G. W. Liddle, and F. C. Bartter. 1956. The effect of changes in body sodium on extracellular fluid volume on aldosterone and sodium excretion by normal and edematous man. J. Clin. Iniest. 35: 1299.

2. Vander, A. J. 1967. Control of renin release. Physiol. Rev. $47: 359$.

3. Krakoff, L. R., F. J. Goodwin, L. Baer, M. Torres, and J. H. Laragh. 1970. The role of renin in the exaggerated natriuresis of hypertension. Circulation. 42: 335 .

4. Kem, D. C., M. H. Weinberger, D. M. Mayes, and C. A. Nugent. 1971. Saline suppression of plasma aldosterone in hypertension. Arch. Intern. Med. 128: 380.

5. Williams, G. H., M. L. Tuck, L. I. Rose, R. G. Dluhy, and R. H. Underwood. 1972. Studies of the control of plasma aldosterone concentration in normal man. III. Response to sodium chloride infusion. J. Clin. Invest. $51: 2645$.

6. Dluhy, R. G., L. Axelrod, R. H. Underwood, and G. H. Williams. 1972. Studies of the control of plasma aldosterone concentration in normal man. II. Effect of dietary potassium and acute potassium infusion. $J$. Clin. Invest. 51: 1950.

7. Williams, G. H., J. P. Cain, R. G. Dluhy, and R. H. Underwood. 1972. Studies of the control of plasma aldosterone concentration in normal man. I. Response to posture, acute and chronic volume depletion, and sodium loading. J. Clin. Invest. 51 : 1731.

8. Mohr, P. A., D. O. Monson, C. Owczarski, and W. C. Shoemaker. 1969. Sequential cardiorespiratory events during and after dextran-40 infusion in normal and shock patients. Circulation. 39: 379.

9. Underwood, R. H., and G. H. Williams. 1972. The simultaneous measurement of aldosterone, cortisol, and corticosterone in human peripheral plasma by displacement analysis. J. Lab. Clin. Med. 79: 848.

10. Emanuel, R. L., J. P. Cain, and G. H. Williams. 1973. Double antibody radioimmunoassay of renin activity and angiotensin II in human peripheral plasma. J. Lab. Clin. Med. $81: 632$.

11. Williams, G. H., L. I. Rose, R. G. Dluhy, D. McCaughn, P. I. Jagger, R. B. Hickler, and D. P. Lauler. 1970. Abnormal responsiveness of the renin aldosterone system to acute stimulation in patients with essential hypertension. Ann. Intern. Med. 72: 317.

12. Snedecor, G. W., and W. G. Cochran. 1967. Statistical Methods. Iowa State University Press, Ames. Iowa. 6th edition. 296.

13. Dunnett, C. W. 1964. New tables for multiple comparisons with a control. Biometrics. 20: 482.

14. Cochran, W. G., and G. M. Cox. 1968. Experimental Designs. John Wiley \& Sons, Inc., New York. 2nd edition. 110.

15. Michelakis, A. M., and R. Horton. 1970. The relationship between plasma renin and aldosterone in normal man. Circ. Res. Suppl. 26-27: 185

16. Best, J. B., J. P. Coghlan, J. H. N. Bett, E. J. Cran, and B. A. Scoggins. 1971. Circulating angiotensin II and aldosterone levels during dietary sodium restriction. Lancet. 2: 1353.

17. Balikian, H. M., A. H. Brodie, S. L. Dale, J. C. 
Melby, and J. F. Tait. 1968. Effect of posture on the metabolic clearance rate, plasma concentration and blood production rate of aldosterone in man. J. Clin. Endocrinol. Metab. 28: 1630.

18. Wolfe, L. K., R. D. Gordon, D. P. Island, and G. W. Liddle. 1966. An analysis of factors determining the circadian pattern of aldosterone secretion. J. Clin. Endocrinol. Metab. 26: 1261.

19. Katz, F. H., P. Romfh, and J. A. Smith. 1972. Episodic secretion of aldosterone in supine man: relationship to cortisol. J. Clin. Endocrinol. Metab. 35: 178.

20. Rosenthal, J., R. Boucher, W. Nowaczynski, and J. Genest. 1968. Acute changes in plasma volume, renin activity, and free aldosterone levels in healthy subjects following fursemide administration. Can. J. Physiol. Pharmacol. 46: 85.

21. Oparil, S., C. Vassaux, C. A. Sanders, and E. Haber. 1970. Role of renin in acute postural homeostasis. Circulation. 41 : 89.

22. Bayard, F., C. L. Alicandri, I. Z. Beitins, G. D. Lubash, A. Kowarski, and C. J. Migeon. 1971. A dynamic study of plasma renin activity and aldosterone concentration in normal and hypertensive subjects. Metab. (Clin. Exp.). 20: 513 .

23. Pickens, P. T., and B. A. Enoch. 1968. Changes in plasma renin activity produced by infusions of dextran and dextrose. Cardiovasc. Res. 2: 157.

24. Michelakis, A. M., and H. Mizukoshi. 1971. Distribution and disappearance rate of renin in man and dog. J. Clin. Endocrinol. Metab. 33: 27.

25. Johnson, J. A., J. O. Davis, J. S. Baumber, and E. G. Schneider. 1971. Effects of hemorrhage and chronic sodium depletion on hepatic clearance of renin. $\mathrm{Am}$. J. Physiol. 220: 1677.

26. Fordtran, J. S., and F. J. Ingelfinger. 1968. Absorption of water, electrolytes and sugars from the human gut. Handb. Physiol. Section 6. 3: 1457.

27. Hunt, J. N., and M. T. Knox. 1968. Regulation of gastric emptying. Handb. Physiol. Section 6. 4: 1917.

28. Nash, F. D., H. H. Rostorfer, M. D. Bailie, R. L. Wathen, and E. G. Schneider. 1968. Renin release: relation to renal sodium load and dissociation from hemodynamic changes. Circ. Res. 22: 473.

29. Hodge, R. L., R. D. Lowe, and J. R. Vane. 1966. Increased angiotensin formation in response to carotid occlusion in the dog. Nature (Lond.). 211: 491.

30. Passo, S. S., T. A. Assaykeen, K. Otsuka, A. Goldfien, and W. F. Ganong. 1971. Effect of stimulation of the medulla oblongata on renin secretion in dogs. Neuroendocrinology. $7: 1$. 